Ann. Biol. anim. Bioch. Biophys., 1978, 18 (4), 1051-1058.

\title{
Photoperiod induced off-season spawning of coho salmon (Oncorhynchus kisutch)
}

\author{
par D. W. MacQUARRIE, J. R. MARKERT, W. E. VANSTONE
}

Nutrition and Applied Endocrinology Program, Resource Services Branch, Fisheries and Marine Service, 4160 Marine Drive, West Vancouver, B. C. Canada V7V 1N6.

Summary. Three groups of coho salmon were reared under artificially controlled photoperiod regimes. One group was exposed to a normal first, second and third year photoperiod cycle. The other two groups were maintained on a normal first but modified second year cycle designed to advance or delay spawning by 120 days. The third cycle was of normal duration but shifted out of phase to maintain the time differences that had been established during the second altered photoperiod cycle.

In December 1975 (the end of the normal second cycle), numbers of precocious males (jacks) and immature fish were determined. Gonadosomatic indices of a subsample of precocious males, immature males and immature females are reported.

Sexually mature adult coho salmon with viable gametes were produced 78-90 days prior to the normal spawning period and 148 days after the normal period. Mortality to swim-up in the fry stage was 8.5 p. 100 in the normal group, 16 p. 100 for the 120 day advanced group and 52 p. 100 for the 120 day delayed group.

Nineteen per cent of the 120 day advanced fish, 17 p. 100 of 120 day delayed fish and 6 p. 100 of the normal fish did not respond to light treatment. They retained their marine colouration and were histologically identified as immature females.

\section{Introduction.}

This study was initiated to determine whether controlled adjustments to the normal rate of change of daylength in the annual photoperiod cycle would induce offseason functional sexual maturity in coho salmon (Oncorhynchus kisutch) similar to that previously demonstrated in pink salmon (O. gorbuscha) (MacQuarrie, Markert and Vanstone, 1978).

Coho salmon usually mature 3 years after egg fertilization. However, sexually precocious 2 yr-old males are observed frequently and 4 yr-old adults occasionally in returns to the spawning grounds. We proposed to develop broodstocks of coho salmon that would spawn 120 days prior to and 120 days later than a normal group of 
3 yr-old adult fish by compressing or expanding the normal rate of change of daylength in their second annual photoperiod cycle.

The rationale for conducting this study was based on the desirability of having groups of swim-up coho fry available regularly throughout the year as test animals for our diet development and salmon aquaculture programs.

\section{Material and methods.}

The period extending from the time of egg fertilization (December 1, 1973) until October 31, 1974, constituted the first phase of this experiment. Up to this time the fish had been reared in well water $\left(10^{\circ} \mathrm{C}\right)$ on a normal photoperiod. If the normal photoperiod cycles continued all fish were expected to reach sexual maturity and spawn in early December, 1976. However, on November 1, 1974 these yearling coho salmon were randomly divided into three groups, each containing 125 fish. These groups of fish were placed into three light proof $3 \mathrm{~m}$ diameter fibreglas tanks containing flowing aerated well water $\left(10^{\circ} \mathrm{C}\right)$ as previously described by MacQuarrie et al. (1978). The interior of each tank was illuminated by four 40 watt Vita Lite fluorescent tubes controlled by a manually adjustable time clock.

During phase II, the fish in each group were subjected to the photoperiod regime they would normally receive to December 20,1975, however, the duration of this phase of the cycle was either compressed by 120 days (group 1) normal (group 2) or expanded by 120 days (group 3). Manually controlled time clocks were adjusted every 10 days during this phase of the experiment. Daylengths (i. e. the time of sunrise and sunset) remained constant for all groups of fish for the initial 10 day interval. However, for the following 10 day intervals the time of sunrise and sunset had been advanced 14 days for group 1,10 days for group 2 and 8 days for group 3 . Thus, a normal 13.7 month cycle was compressed into 9.7 months for group 1 or expanded into a 17.7 month cycle for group 3 (fig. 1).

The experiment was continued into phase III using a normal, but still artificially controlled photoperiod shifted out of phase by time clocks (which automatically adjust themselves for seasonal changes in daylength) to maintain the time differences established during phase II. Spawning was expected to occur in early December 1976 for group 2 fish and in what was apparently early December 1976 for groups 1 and 3.

During the experiment the fish were fed Oregon moist pellets (OMP II) ad lib. twice daily.

Smolts in group 2 were acclimated to flowing aerated salt water at ambient temperature in May 1975 as occurs normally for wild fish. Fish in groups 1 and 3 were acclimated to salt water in what was apparently May 1975 (March 1975-group 1 ; July 1975-group 3).

The fish were sampled in December 1975. i. e. the end of the normal second cycle for group 2. Weights, gonadosomatic indices and numbers of precocious males and immature fish were recorded (table 1). The number of fish/tank was also reduced at this time so that group 1 had 53, group 2, 55 and group 3, 62 fish. 


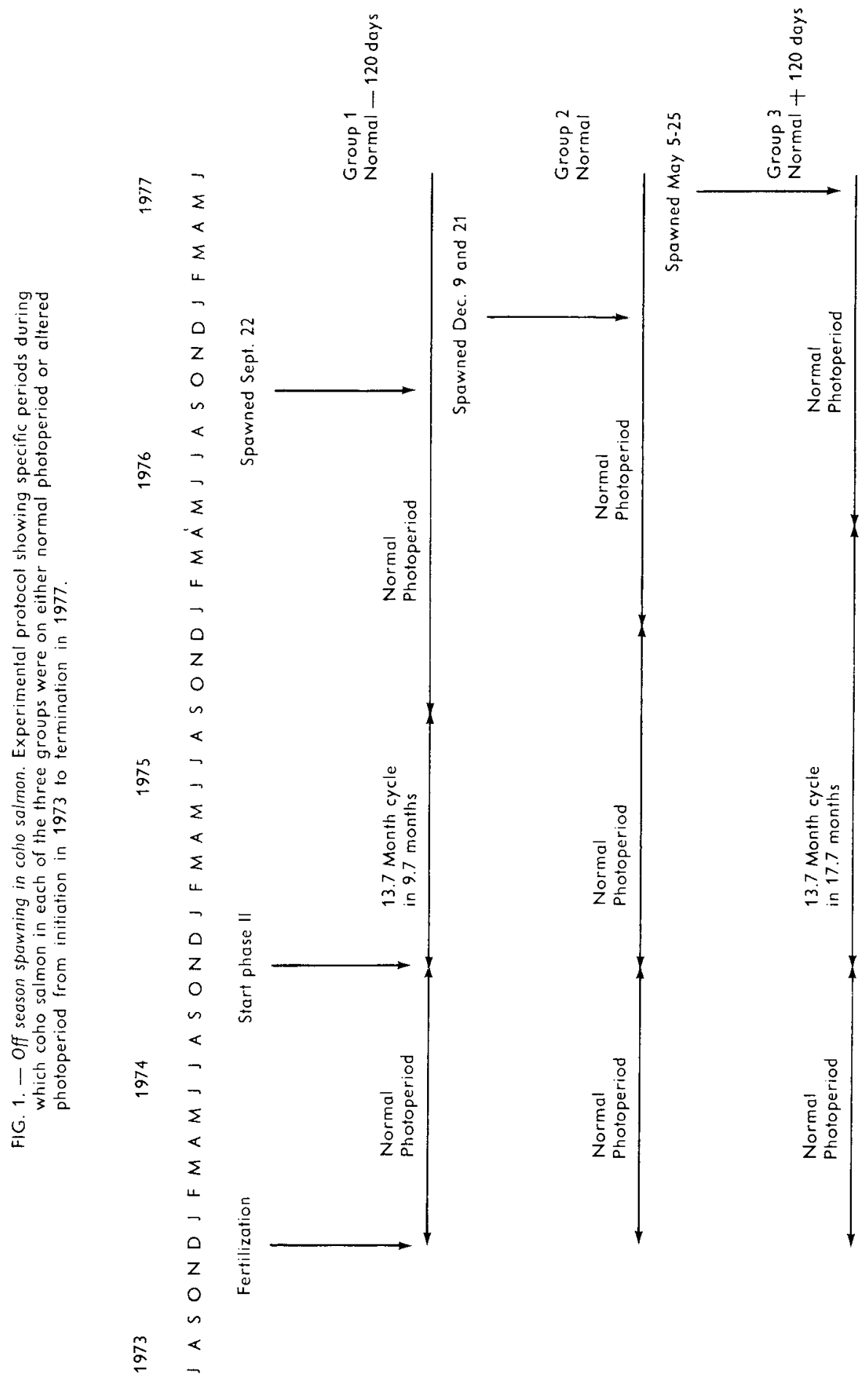


TABLE 1

Mean weight and GSI $\bar{x} \pm S D$ of coho solmon exposed to normal or altered photoperiod regimes

\begin{tabular}{|c|c|c|c|}
\hline Group & 1 & 2 & 3 \\
\hline 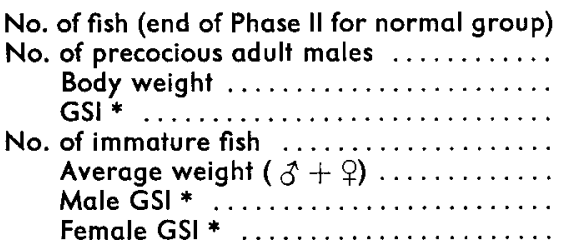 & $\begin{array}{c}91 \\
9 \\
166.6 \\
7.0 \pm 1.0 \\
82 \\
99.3 \\
0.05 \pm 0.01 \\
0.35 \pm 0.09\end{array}$ & $\begin{array}{c}108 \\
25 \\
189.0 \\
6.9 \underset{83}{ \pm 2.0} \\
202.8 \\
0.07 \pm 0.02 \\
0.40 \pm 0.12\end{array}$ & $\begin{array}{c}117 \\
37 \\
282.7 \\
3.9 \pm 0.9 \\
80 \\
90.9 \\
0.07 \pm 0.01 \\
0.40 \pm 0.07\end{array}$ \\
\hline
\end{tabular}

* Estimated following a sampling of 4 to 7 fish/group.

All groups of fish were reacclimated to $10^{\circ} \mathrm{C}$ well water when they started to take on their breeding colouration. They were lightly anaesthetized with 2-phenoxyethanol $(0.07 \mathrm{ml} / \mathrm{l})$ and examined for maturity prior to, during and after the expected spawning period. When the fish were ready to spawn, they were stunned, weighed and measured and then the eggs were stripped and fertilized. Weights and numbers of eggs were determined within 15 min of fertilization. The eggs were allowed to water harden for $2 \mathrm{hr}$ and were then placed in Heath trays and incubated in flowing $(12 \mathrm{l} / \mathrm{min})$ aerated $10^{\circ} \mathrm{C}$ well water. Dead eggs were removed after the eyed stage, cleared using Stockard's solution and numbers of fertilized and non-fertilized ova were recorded (table 4).

\section{Results.}

On December 30,1975 (the end of the normal second cycle) an inventory of each group revealed (table 1) that 9.9 p. 100 (group 1) 23.1 p. 100 (group 2) and 31.6 p. 100 (group 3) of the fish were precocious males (jacks). The gonadosomatic indices of these fish were significantly different : 120 day advanced $>120$ day delayed ; normal $>120$ day delayed. There was no significant difference between the normal group and the 120 day advanced group (one way ANOVA and Scheffe's test $P=$ 0.05). A subsample (4-7 fish/group) from the remaining immature fish showed that there was no significant difference between the gonadosomatic indices of immature males or between immature females in the three groups (one way ANOVA).

Data in table 2 indicate that the first mature male coho salmon was observed just prior to (groups 2 and 3), or just after (group 1) the expected spawning date. However, the time interval between the expected spawning date (time 0 ), the observation of the first partially ovulated female (a) and the actual time the majority of the females were spawned (b) range from : (a) +37 days (b) +53 days for group 1 ; (a) -8 days 
(b) +9 days for group 2 ; to (a) +19 days, (b) +35 days for group 3 . Only the normal group (group 2) spawned close to the expected date.

TABLE 2

Expected, actual and apparent spawning dates for 3 groups of coho salmon exposed to normal or altered photoperiod regimes

\begin{tabular}{|c|c|c|c|}
\hline Group & 1 & 2 & 3 \\
\hline $\begin{array}{l}\text { Spawning date } \\
\text { Expected } \ldots \ldots \ldots \\
\text { Actual. ......... } \\
\text { Apparent } \ldots \ldots\end{array}$ & $\begin{array}{l}\text { August } 1,1976 \\
\text { September } 22,1976 \\
\text { January } 20,1977\end{array}$ & $\begin{array}{l}\text { December } 1,1976 \\
\text { December } 9 \text { and } 21,1976 \\
\text { December } 9 \text { and 21, } 1976\end{array}$ & $\begin{array}{l}\text { April } 1,1977 \\
\text { May } 2,5,17 \text { and } 25,1977 \\
\text { January } 18 \text { and } 21,1977 \\
\text { February } 2 \text { and } 10,1977\end{array}$ \\
\hline $\begin{array}{l}\text { First partially ovulated } \\
\text { female } \ldots \ldots \ldots \ldots \ldots \\
\text { First mature male } \ldots \ldots\end{array}$ & $\begin{array}{l}\text { September 7, } 1976 \\
\text { August 2, } 1976\end{array}$ & $\begin{array}{l}\text { November 22, } 1976 \\
\text { October } 27,1976\end{array}$ & $\begin{array}{l}\text { April 19, } 1977 \\
\text { March 25, } 1977\end{array}$ \\
\hline
\end{tabular}
table 3.

Numbers, lengths and weights of breeding males and females are recorded in

The ovulatory response of breeding coho salmon females is also reported in table 3. All of the females in group 1 had completely ovulated. Eighty-six per cent of the females in group 2 and 64 p. 100 of the group 3 females had also reached this stage.

TABLE 3

Lengths (mean $\pm \mathrm{SD}$ ), weights (mean $\pm \mathrm{SD}$ ), gonadosmotic index (mean $\pm \mathrm{SD}$ ) at spawning for coho salmon exposed to normal or altered photoperiod regimes

\begin{tabular}{|c|c|c|c|c|c|c|}
\hline \multirow[b]{2}{*}{ 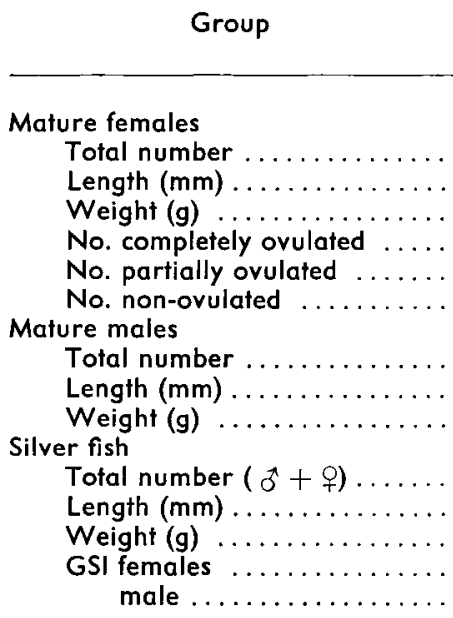 } & \multicolumn{2}{|r|}{1} & \multicolumn{2}{|r|}{2} & \multicolumn{2}{|r|}{3} \\
\hline & $\begin{array}{r}350.7 \\
506.1 \\
\\
300.5 \\
312.8 \\
0.95\end{array}$ & $\begin{array}{l}11 \\
\pm \quad 23.2 \\
\pm \\
\frac{11}{11} \\
0 \\
0 \\
\\
14 \\
\pm \quad 42.5 \\
\pm 173.8 \\
6 \\
\pm \quad 38.9 \\
\pm \\
\pm \quad 117.8 \\
\pm \quad 0.32\end{array}$ & $\begin{array}{r}280.0 \\
271.1 \\
0.81 \\
1.12\end{array}$ & $\begin{array}{l}35 \\
\pm \quad 22.7 \\
\pm 139.3 \\
30 \\
3 \\
2 \\
\\
13 \\
\pm \quad 25.0 \\
\pm 124.3 \\
3 \\
\pm \quad 60.0 \\
\pm 152.8 \\
\pm \quad 0.04\end{array}$ & $\begin{array}{r}340.0 \\
448.5 \\
4.56\end{array}$ & $\begin{array}{l}11 \\
+\quad 31.1 \\
\pm 163.2 \\
7 \\
3 \\
1 \\
9 \\
\pm \quad 42.3 \\
\pm 255.8 \\
4 \\
\pm \quad 33.7 \\
\pm 125.0 \\
\pm \quad 8.1 *\end{array}$ \\
\hline
\end{tabular}

* One had GSI of 16.7 . 
Information in table 3 also indicates that group 1 had 19.4 p. 100 and group 3 , 16.7 p. 100 immature silver fish present. Only 5.9 p. 100 of these immature fish were observed in group 2 during the spawning period. With only one exception, all of the immature fish were histologically identified as females. One immature male was present in group 2 (had one blind eye).

Female fecundity (table 4) was also greatly reduced in the three experimental groups when compared to wild females and ranged from 645 to 803 eggs/female. It was apparent that longer growing periods resulted in larger mean weights for the ova (group $3>$ group $2>$ group 1 ). It was also evident that egg and alevin mortality (table 4) increased slightly for group 1 (16.15 p. 100) and markedly for group 3 (52.0 p. 100) when compared with the normal group ( 8.51 p. 100$)$. The high egg

TABLE 4

Female fecundity; mean egg weight and viability of ova and alevins obtained from 3 groups of coho salmon exposed to normal or altered photoperiod regimes

\begin{tabular}{|c|c|c|c|}
\hline Group & 1 & 2 & 3 \\
\hline $\begin{array}{l}\text { Number of eggs stripped.......... } \\
\text { Number of eggs/female (av.) ..... } \\
\text { Number of eggs/kg body weight } \ldots \\
\text { Average egg weight (g) } \ldots \ldots \ldots \ldots \\
\text { Percentage of eyed eggs } \ldots \ldots \ldots \ldots \\
\text { Percentage of fry at swim-up ...... }\end{array}$ & $\begin{array}{c}7096 \\
645 \\
1060.3 \\
0.160 \\
84.9 \\
83.9\end{array}$ & $\begin{array}{c}24934 \\
792 \\
990.8 \\
0.174 \\
93.6 \\
91.5\end{array}$ & $\begin{array}{l}5733 \\
803 \\
942.8 \\
0.187 \\
50.4 \\
48.0\end{array}$ \\
\hline
\end{tabular}

losses experienced by group 3 can be attributed to the very large percentage of nonfertilized eggs which were present (47.4 p. 100 non-fertilized group 3, 15.1 p. 100 non-fertilized group 1 and 6.4 p. 100 non-fertilized in group 2).

\section{Discussion.}

Photoperiod manipulation induced off-season functional sexual maturity in coho salmon. However, if the main spawning date for each group is taken into consideration (group 1-September 22, 1976 ; group 2 - December 9, 1976 ; group 3 - May 5 , 1977) then group 1 spawned 78 days prior to and group 3 spawned 148 days later than the normal group rather than at the expected 120 day interval. A similar 4-6 week spawning delay was also reported for pink salmon reared on manipulated photoperiods (MacQuarrie ef al., 1978). This spawning delay might be attributed to the effects of captivity such as high rearing density, artificial lighting, an artificial diet, nutritional status, temperature cycles out of phase with photoperiod, handling, etc. Wild adult coho salmon spawn from October to January.

Scott and Crossman (1973) state that average lengths and weights of adult coho salmon range from 457 to $610 \mathrm{~mm}$ and from 3628 to $5443 \mathrm{~g}$, respectively. It is readily apparent that fish in all experimental groups reached only a fraction of the size they 
could have attained in the wild environment. Foerster and Pritchard (1941) suggest that small adult females produce fewer eggs. This observation might explain the marked reduction in fecundity of the experimental fish when compared to the 2100 to $2789 \mathrm{egg}$ average reporied for British Columbia's adult coho (Scott and Crossman, 1973). The eggs generated by fish in groups 1 and 2 were of good quality as demonstrated by their relatively low rates of mortality to swim-up.

Prespawning mortalities occured in group 3. Four mature males and 2 maturing females (GSI 15.4 and 15.8) died within one month of spawning. Forty-seven per cent of the ova produced by this group were not fertilized. As these eggs were treated in the same manner as ova in groups 1 and 2 with respect to methods of collection, insemination and incubation it implies that either the eggs or sperm were of poor quality. However, as ripe males were observed in group 1 seven weeks and in group 3 six to eight weeks prior to spawning, one might conclude that the sperm produced by both groups of fish would have the same potential to fertilize the eggs. Immature, silver fish which did not respond to the photoperiod treatment (Hazard and Eddy, 1951 ; MacQuarrie et al., 1978) were also observed in this experiment (these fish might mature as 4 yrolds). It was interesting to note that all but one of these fish were females. MacQuarrie ef al. (1978) indicated that all immature pink salmon ( 0 . gorbuscha) present at spawning were females. It appears evident that it is much more difficult to induce off-season functional sexual maturity in female Pacific salmon. Even if successful in inducing these fish to mature, not all of the females will produce viable ova as the more complicated, rigorously scheduled progression of events that occurs during vitellogenesis might be disrupted by manipulative changes in the photoperiod cycle.

The present work on off-season induction of sexual maturity in coho salmon has demonstrated that it is feasible to produce viable alevins at spaced intervals throughout he year to satisfy the requirements of various experimental programs or to initiate new studies at times when swim-up fry are not available.

Symposium sur la Reproduction des Poissons Poimpont, France, 19-21 septembre 1977.

Acknowledgments. - We appreciate the contributions that A. Lamb, J. Heading and B. Corrigan made to this study by their skillful care and attention of the experimental fish. We thank Mrs. M. Young for typing the manuscript.

Résumé. Trois groupes de saumons coho sont élevés sous des photopériodes artificielles contrôlées. Un groupe est exposé à trois cycles photopériodiques annuels normaux. Pour les deux autres groupes, la première année le cycle est normal, mais la seconde année il est modifié pour avancer ou retarder la fraie de 120 jours. Le troisième cycle est de durée normale, mais déplacé pour maintenir les différences temporelles établies au cours du second cycle photopériodique modifié.

En décembre 1975 (fin du second cycle normal), le nombre de mâles précoces (Jacks) ef de poissons immatures est déterminé. Les rapports gonadosomatiques d'un échantillon de mâles précoces, de mâles immatures et de femelles immatures sont rapportés. Les mâles adultes sexuellement matures, sont produits $78-90$ jours avant la période normale de fraie et de 148 jours après la période normale. La mortalité jusqu'au stade de nage libre des 
alevins est de 8,5 p. 100 dans le groupe normal, 16 p. 100 pour le groupe avancé de 120 jours et 52 p. 100 pour le groupe retardé de 120 jours.

19 p. 100 de poissons avancés de 120 jours, 17 p. 100 de poissons retardés de 120 jours et 6 p. 100 de poissons normaux ne répondent pas au traitement lumineux. Ils conservent leur coloration marine et sont identifiés en histologie comme des femelies immatures.

\section{References}

FOERSTER R. E., PRITCHARD A. L., 1941. Observations on the relation of egg content to total length and weight in the sockeye salmon (Oncorhynchus nerko) and pink salmon (O. gorbuscha). Trans. r. Soc. Can., 35, 51-60.

HAZARD T. P., EDDY R. E., 1951. Modification of the sexual cycle in brook trout (Salvelinus fontinalis) by control of light. Trans. amer. Fish. Soc. (1950), 80, 158-162.

MacQUARRIE D. W., MARKERT J. R., VANSTONE W. E., 1978. Photoperiod induced off-season spawning of pink salmon (Oncorhynchus gorbuscha) (in preparation).

SCOTT W. B., CROSSMAN E. J., 1973. Freshwater Fishes of Canada. Fish. Res. Bd. Can., Bull. 184. 